\title{
UK Geological Survey offered alternative for a new future
}

\section{London}

A RADICAL change of the relationship between the British Geological Survey (BGS) and its present sponsor, the Natural Environment Research Council (NERC), is advocated by a committee under Sir Clifford Butler whose report* is published this week. The committee says that both the status and the independence of BGS should be enhanced by separation from NERC and by direct accountability to a senior minister, such as the Secretary of State for the Environment.

That BGS has been in trouble has been known for some time (see Nature 311, 499; 1984). Its core task of carrying out and publishing a geological survey of the United Kingdom was at one stage nearly squeezed out of existence by the pressure to provide research commissioned by government departments and by industry at a time when its funds and manpower were being reduced. Although the subvention from NERC has recently been increased, the Butler committee considers that these steps will not remedy the situation. Among specific criticisms are the following:

Publication of BGS survey maps is too infrequent, partly because senior survey staff are perfectionists. BGS has let lapse the arrangements under which groups of experts concentrate on specific areas, becoming in the process overdependent on generalists.

NERC has paid too little attention to the maintenance of survey work, while government departments have had too much influence on BGS policy.

- The Butler committee "has the impression" that the NERC council lacks the "time and distinctive expertise, especially of market needs", to provide "helpfully and in detail" an appraisal of BGS's programmes. It acknowledges that NERC has other demands upon it, but says that the secrecy surrounding the findings of invigalatory visting groups "limits the value of their work".

The appointment of a Director of Earth Sciences at NERC's headquarters is described as "highly disadvantageous" in that it entails "the interposition of another layer of management above BGS and the consequent diminution of the role of its director".

Specifically, the committee says that BGS should be guaranteed $£ 18$ million a year (index-linked) exclusively for its programme of structural, geochemical and hydrological surveys, including the development of a digital National Geo-

This is the first issue of Nature to be printed in Japan. sciences Data Centre. BGS would also be encouraged to sell data in its control, keeping the receipts, and would be allowed to make contracts with government departments and industrial companies provided the former included a surcharge of 20 per cent (to help with basic research) and that the latter were struck at commercial rates to ensure that BGS could not compete unfairly with private survey companies.

The Butler committee offers alternative schemes for a new organization, preferring that in which BGS would acquire an independent corporate identity somewhat like the present constitution of the British Ordnance Survey. Failing that, the committee would prefer to see BGS attached to a government department than to remain with NERC.

The report was commissioned jointly by NERC and the Advisory Board for the Research Councils, the second of which is likely to be responsible for recommending which course of action should be followed. The committee considers that a change of status could be carried through in time for the financial year beginning in April 1989. Philip Campbell

${ }^{*}$ Report of the study group into geological surveying.

\section{French commission}

\section{Paris}

Following the violent reception of his predecessor's attempt to institute reforms in French higher education, Jacques Valade, minister for research and higher education has set up a panel of 69 academic advisers. Divided into five working groups, the panel will prepare a document entitled Tomorrow's University for discussion at the end of 1987 . Themes for the respective working parties are 'evaluation', 'research and transfer of technology', 'scientific employment', 'the provinces' and 'research funding'. The aim of the commission and its report is to reevaluate, "from scratch", the role of the University in France.

P.R.C.

\section{India off in parallel}

Bangalore

INDIA is to begin a new project aimed at the indigenous development of parallel computing systems. The Prime Minister, Rajiv Gandhi, has authorized the Science Advisory Council to launch the project this year, with the goal of producing a 50 megaflop [million floating-point operations per second] machine within three years. A budget of $\$ 14.25$ in foreign exchange and $\mathbf{R 1 2 . 8 5}$ crore in Indian currency is expected.
AIDS workers back on speaking terms

Washington

THE controversy over the potential of peptide $\mathrm{T}$ as a treatment for AIDS (acquired immune deficiency syndrome) remained unresolved after a special meeting at the National Institute of Mental Health (NIMH) last week. But the meeting did succeed in returning a conflict dramatized by the media to the realms of normal scientific debate - and opinions did change.

No new data were presented to change substantially the views of the Food and Drug Administration, which will still give permission for clinical trials, provided that certain technical details are provided by NIMH.

Controversy over peptide $\mathrm{T}$ erupted at last month's Third International Conference on AIDS when several laboratories claimed that they had been unable to replicate the findings of the discoverer of peptide T, Dr Candace Pert of NIMH (Nature 327, 449; 1987). Pert has published evidence that peptide $\mathrm{T}$ can inhibit the entry of human immunodeficiency virus (HIV) into cells. In her view, peptide T blocks viral entry because it corresponds to the sequence that binds the HIV envelope glycoprotein (gp120) to the cell surface receptor (T4 or CD4).

That hypothesis is now under siege. Dr Joseph Sodroski and colleagues at the Dana-Faber Institute and Dr Larry Lasky at Genentech analysed the regions of the gp120 envelope glycoprotein responsible for binding. Sodroski reports that by introducing mutations into the envelope glycoprotein he finds three regions are involved, none of them containing peptide $T$. And in straightforward syncitial assays already published in the Lancet, Sodroski shows that peptide $\mathrm{T}$ does not interfere with gp120-CD4 binding.

These experiments do not, however, call into question the evidence that peptide $\mathrm{T}$ has some antiviral action. Work by Elaine Thomas at Genetic Systems Inc. and by Pert's collaborators confirm that peptide $\mathrm{T}$ can inhibit viral infection in a number of different assay systems. To see the effect the experimental conditions have to be exactly right. Thomas's work clearly shows that antiviral effects present at low concentrations of virus (themselves compatible with biological levels) disappear at higher levels. Experimenters who have not found the effect may have been on the wrong part of the curve.

Researchers now seem likely to look for non-specific antiviral effects of peptide $\mathrm{T}$ in cells which do not bear the CD4 receptor.

Alun Anderson 